\title{
SAFEGUARD OF THE POLICE INTELLIGENCE AGAINST COURT DECISIONS REGARDING THE OBJECT OF THE DISPUTE
}

\author{
La Ode Husen ${ }^{1 *}$, Salle Salle ${ }^{2}$, Arri Abdi Syalman ${ }^{3}$, Abd. Kahar Muzakkir ${ }^{4}$ \\ ${ }^{1}$ Professor of the Faculty of Law, Universitas Muslim Indonesia, Makassar \\ ${ }^{2}$ Lecturer of the Faculty of Law, Universitas Muslim Indonesia, Makassar \\ ${ }^{3}$ Doctoral Student of Legal Studies Program, Universitas Muslim Indonesia, Makassar \\ ${ }^{4}$ Editor of the Publisher of CV. Social Politic Genius (SIGn), Indonesia \\ *Correspondence Author: La Ode Husen \\ Email Correspondence: laode.husen@umi.ac.id
}

\begin{abstract}
This study aims to analyze the effectiveness of safeguard of the Police Intelligence against court decisions regarding the object of the dispute in South Sulawesi Province. This research uses an empirical study method which is also called sociological legal research because it sees the application of law as a factual condition in the social environment and its relationship with legal norms. This research was conducted in South Sulawesi Province, with 92 respondents. Data analysis in this study uses a qualitative approach, which processes the output of the questionnaire, and is presented in the form of frequency tabulation (F) and percentage distribution (\%). The results of this study show that the safeguard of South Sulawesi Regional Police Ditintelkam in the execution process regarding the object of the dispute in South Sulawesi Province based on Perkap BIN No. 2 of 2013, can be assessed from four aspects, as follows: Safeguarding Targets; Safeguarding Implementation; Coordination and Administration; and Supervision and Controlling. Data acquisition of all indicators based on safeguard aspects of the South Sulawesi Regional Police Ditintelkam still shows less effective results. Seriousness is needed in increasing the safeguard effectiveness at the South Sulawesi Regional Police Ditintelkam to ensure the process of executing court decisions regarding the object of the dispute can be more effective in the future.
\end{abstract}

Keywords:

Court Decisions;

Dispute Object;

Effectiveness of Safeguard;

Execution;

Regional Police Ditintelkam.

\section{INTRODUCTION}

Provisions for the Preamble to the 1945 Constitution of the Republic of Indonesia state that Indonesia is a state of law (rechtsstaat) so that the legal position must be placed above all else. ${ }^{1}$ The law covers all the behavior of citizens. Furthermore, the rule of law

${ }^{1}$ Husen, La Ode \& Thamrin, Husni. (2017). Hukum Konstitusi: Kesepakatan (Agreement) dan Kebiasaan (Custom) Sebagai Pilar Konvensi Ketatanegaraan. Makassar: CV. Social Politic Genius (SIGn), p. 13. 
requires the government to serve the needs of all its citizens, without discrimination based on the origin, religion, or social strata of its citizens. ${ }^{2}$

The realization of order and balance in social life is the main goal of law enforcement so that the interests of every citizen must and remain protected. ${ }^{3}$ Furthermore, there are three elements in law enforcement, including legal certainty, the usefulness of law, and justice. ${ }^{4}$ These three elements are practiced in court decisions, one of which is a court decision regarding the object of the dispute. The court's decision adheres to the force of execution which is a manifestation of permanent legal force so that each execution of a court's decision cannot be postponed. ${ }^{5}$

The execution is not carried out if the losing party voluntarily accepts and implements a court decision. If not, execution can be carried out even in the form of forced execution. ${ }^{6}$ The source of law inherent in the power of execution, according to Djazuli Bachar consists of: ${ }^{7}$

1. Civil Procedure Law;

2. Other relevant laws;

3. Regulations of the Supreme Court of the Republic of Indonesia; and

4. Circular of the Supreme Court of the Republic of Indonesia.

On the other hand, to ensure the execution process runs as expected, it can involve the police to provide safeguarding and protection for the executors of court decisions regarding objects of dispute. ${ }^{8}$ This is as based on Article 15 paragraph (1) letter l Law of the Republic of Indonesia Number 2 of 2002 on the State Police of the Republic of Indonesia (hereinafter referred to as Law No. 2 of 2002) regulates that:

"In implementing its tasks ..., the State Police of the Republic of Indonesia shall authorize generally to provide safeguarding assistances in the hearing process and the execution of the court ruling, other institutional activities and public activities."

Based on the above provisions, the police in provide safeguarding assistance must involve the Police Intelligence Agency based on Article 3 Law of the Republic of Indonesia Number 17 of 2011 on State Intelligence (hereinafter referred to as Law No.

\footnotetext{
${ }^{2}$ Qamar, Nurul, et al. (2018). Negara Hukum atau Negara Kekuasaan (Rechtsstaat or Machtstaat). Makassar: CV. Social Politic Genius (SIGn), p. 2.

${ }^{3}$ S., Laurensius Arliman. (2019). Mewujudkan Penegakan Hukum yang Baik di Negara Hukum Indonesia. Dialogia Iuridica: Jurnal Hukum Bisnis dan Investasi, Universitas Kristen Maranatha, 11(1), p. 12.

${ }^{4}$ Sagama, Suwardi. (2016). Analisis Konsep Keadilan, Kepastian Hukum dan Kemanfaatan dalam Pengelolaan Lingkungan. Mazahib: Jurnal Pemikiran Hukum Islam, Institut Agama Islam Negeri Samarinda, 15(1), p. 22.

${ }^{5}$ Pratama, Widhy Andrian. (2019). Penegakan Hukuman Mati terhadap Pembunuhan Berencana. SIGn Jurnal Hukum, CV. Social Politic Genius (SIGn), 1(1), p. 35.

${ }^{6}$ Jebabun, Alfeus, et al. (2018). Asesmen Awal Permasalahan Eksekusi Putusan Perkara Perdata di Indonesia. Jakarta: Lembaga Kajian dan Advokasi untuk Independensi Peradilan (LeIP) in collaboration with International Development Law Organization (IDLO), p. 9.

${ }^{7}$ Bachar, Djazuli. (2008). Eksekusi Putusan Perkara Perdata: Segi Hukum dan Penegakan Hukum. Jakarta: Akademika Pressindo, p. 12.

${ }^{8}$ Sonata, Depri Liber. (2012). Permasalahan Pelaksanaan Lelang Eksekusi Putusan Pengadilan dalam Perkara Perdata dalam Praktik. Fiat Justisia: Jurnal Ilmu Hukum, Universitas Lampung, 6(2), p. 17.
} 
17 of 2011) regulates that "essentially, State Intelligence is the first line in the national security system".

Furthermore, safeguard is one of the intelligence tasks within the scope of the police, which is carried out by applying procedures, methods, techniques, and tactics, to create security and order in the life of the nation and state. ${ }^{9}$ Therefore, the role of the Intelligence Police in carrying out their duties includes ensuring the safeguard of the implementation of the object of the dispute so as to create a condition of security and order in the community.

Based on the description above, this study aims to analyze the effectiveness of safeguard of the Police Intelligence against court decisions regarding the object of the dispute in South Sulawesi Province. The benefit of this research is the effort to find out the safeguard pattern of the involvement of the Intelligence Police during the implementation of the disputed object, especially in the South Sulawesi Province.

\section{METHOD}

This research uses an empirical study method which is also called sociological legal research because it sees the application of law as a factual condition in the social environment and its relationship with legal norms. ${ }^{10}$ This research was conducted in South Sulawesi Province, with 92 respondents. Furthermore, the types and sources of data consist of primary and secondary data, where primary data is obtained directly at the research location through an interview process, while secondary data is obtained from research results using library materials such as Books, Scientific Articles, Legislation, official documents, and other people's writings that have relevance to the discussion of this study. Data analysis in this study uses a qualitative approach, which processes the output of the questionnaire, and is presented in the form of frequency tabulation (F) and percentage distribution (\%).

\section{RESULTS AND DISCUSSION}

Execution has the same meaning as carrying out a decision (ten uitvoer legging van vonnissen), where implementation can be carried out "by force" with the help of law enforcement if the losing party does not heed the court decisions regarding the object of the dispute. ${ }^{11}$ In general, the implementation of procedural rules related to the execution of court decisions regarding the object of the dispute in Indonesia is regulated in Staatsblad Number 44 of 1941 on Herzien Inlandsch Reglement (hereinafter referred

\footnotetext{
${ }^{9}$ Harefa, Herius, Fitriati, Fitriati, \& Ferdi, Ferdi. (2018). Optimalisasi Fungsi Intelijen Kepolisian dalam Penyelidikan Tindak Pidana Narkotika yang Dilakukan Anggota Kepolisian (Studi Sat Intelkam Polres Solok). Unes Law Review, Universitas Ekasakti Padang, 1(1), p. 48.

${ }^{10}$ Husen, La Ode, et al. (2020). Pengamanan Intelijen Kepolisian Terhadap Putusan Pengadilan Atas Objek Sengketa. SIGn Jurnal Hukum, CV. Social Politic Genius (SIGn), 1(2), p. 138.

${ }^{11}$ Harahap, M. Yahya. (2007). Ruang Lingkup Permasalahan Eksekusi Bidang Perdata. Jakarta: PT. Gramedia Pustaka Utama, p. 5.
} 
to as HIR). ${ }^{12}$ Furthermore, the execution process based on Article 197 paragraph (1) of the HIR regulates that:

"If it has passed the specified maturity, and the person who was defeated hasn't fulfilled that decision, or if he was called correctly, but did not come, then the chairman because of his position gave orders by letter, so all properties are not permanent must be confiscated and if there isn't, or it seems like there aren't many properties of people being defeated until it is deemed sufficient to replace the amount of money stated in the decision and added all costs to implement the decision."

The executor of the court decisions regarding the object of the dispute, based on Article 54 paragraph (2) Law of the Republic of Indonesia Number 48 of 2009 on The Judicial Powers (hereinafter referred to as Law No. 48 of 2009) regulates that "Implementation of court decisions in civil cases is carried out by clerks and bailiffs led by the chairman of the court".

If it is deemed the execution process will present an unsafe disturbance/condition for the object of the dispute, then the executor can ask the police for help, ${ }^{13}$ as based on Article 197 paragraph (9) of the HIR regulates that:

"Clerks or person appointed to replace it, according to the circumstances, according to circumstances, can leave properties are not permanent or some of it was in the storage of the person whose properties were confiscated, or instruct to bring several properties to the appropriate storage area. In the first case, so he told the village police, and the police must guard it so that none of the properties is taken away. Opstal Indonesia cannot be taken anywhere else."

Based on the above provisions, the involvement of the police is a must, as according to Satjipto Rahardjo that: ${ }^{14}$

"The police are the tools of the state whose duty is to maintain the security and order of the people, provide protection, and provide protection to the public."

In the context of the effectiveness of the duties of the police force considering that Indonesia is an archipelagic country, then based on Article 6 paragraph (2) Law No. 2 of 2002 regulates that:

"In implementing its roles and functions, the state territory of the Republic of Indonesia shall be divided within legal regions based on the interest of tasks implementation of the State Police of the Republic of Indonesia."

Based on the provisions above and based on the current context so that the Regulation of the State Police of the Republic of Indonesia Number 14 of 2018 on Organization Structure and Work Procedure of the Regional Police (hereinafter referred to as

\footnotetext{
${ }^{12}$ Aziezi, M. Tanziel, et al. (2019). Kertas Kebijakan Penguatan Sistem Eksekusi Sengketa Perdata di Indonesia. Jakarta: Lembaga Kajian dan Advokasi untuk Independensi Peradilan (LeIP), p. 9; Vide Editorial. (2018, 19 April). Eksekusi dalam Teori dan Praktek. In Fakultas Hukum Universitas Indonesia. Retrieved at the date on February 28, 2020.

${ }^{13}$ Penyusun (Ed.) (2019). Pedoman Eksekusi pada Pengadilan Negeri. Jakarta: Direktorat Jenderal Badan Peradilan Umum, Mahkamah Agung RI, p. 40.

${ }^{14}$ Rahardjo, Satjipto. (2009). Penegakan Hukum: Suatu Tinjauan Sosiologis. Yogyakarta: Genta Publishing, p. 111.
} 
PerPolri No. 14 of 2018) was ratified. Furthermore, to ensure the maintenance of security in the regions, one of the functions of the Police is based on Article 4 letter $b$ PerPolri No. 14 of 2018 regulates that:

"In implementing tasks ..., the Regional Police enforce the implementation function of the security intelligence for interference prevention and preservation of national security"

Furthermore, based on Article 1 point 18 PerPolri No. 14 of 2018 explains that:

"Directorate of Security Intelligence hereinafter referred to as Ditintelkam is the implementing elements of the main task in the field of security intelligence at the Regional Police level under the Head of Regional Police."

From the above provisions and to ensure the safeguarding role of Police Intelligence, both in the National Police Headquarters to the Regional Police, Regulation of the Head of Security Intelligence Agency of the State Police of the Republic of Indonesia Number 2 of 2013 on Safeguard of the State Police Intelligence of the Republic of Indonesia (hereinafter referred to as Perkap BIN No. 2 of 2013) was ratified. Perkap BIN No. 2 of 2013 contains aspects of safeguard of the Police Intelligence that are divided based on the provisions of this Chapter, including:

1. Safeguarding Targets;

2. Safeguarding Implementation;

3. Coordination and Administration; and

4. Supervision and Controlling.

Research that has been carried out is related to the safeguard effectiveness of South Sulawesi Regional Police Ditintelkam in the execution process regarding the object of the dispute in South Sulawesi Province based on Perkap BIN No. 2 of 2013, the four aspects will be explained one by one, as follows:

\section{A. Safeguarding Targets}

Based on Article 4 Perkap BIN No. 2 of 2013 regulates that safeguarding targets of the State Police Intelligence of the Republic of Indonesia includes:
a. people/personnel;
b. object/material/installation/place/location;
c. activity; dan
d. data/information.

The results of interviews with respondents regarding effectiveness based on aspects of safeguarding targets of South Sulawesi Regional Police Ditintelkam can be seen in the following table: 
Table 1. Safeguard Effectiveness of South Sulawesi Regional Police Ditintelkam based on Aspects of Safeguarding Targets

\begin{tabular}{c|l|c|c|c|c|c|c|c|c}
\hline \multirow{2}{*}{ No. Indicator } & \multicolumn{2}{|c|}{ Effective } & \multicolumn{2}{c|}{$\begin{array}{c}\text { Less } \\
\text { Effective }\end{array}$} & \multicolumn{2}{c|}{ Ineffective } & \multicolumn{2}{|c}{ Total } \\
\cline { 3 - 11 } & & $\mathbf{F}$ & $\mathbf{\%}$ & $\mathbf{F}$ & $\mathbf{\%}$ & $\mathbf{F}$ & $\mathbf{\%}$ & $\mathbf{F}$ & $\mathbf{\%}$ \\
\hline \hline 1. & People/Personnel & 28 & 30,43 & 47 & 51,09 & 17 & 18,48 & 92 & 100 \\
\hline 2. & $\begin{array}{l}\text { Object/Material/Installation/Place/ } \\
\text { Location }\end{array}$ & 19 & 20,65 & 59 & 64,13 & 14 & 15,22 & 92 & 100 \\
\hline 3. & Activity & 28 & 30,44 & 52 & 56,52 & 12 & 13,04 & 92 & 100 \\
\hline 4. & Data/Information & 19 & 20,65 & 57 & 61,96 & 16 & 17,39 & 92 & 100 \\
\hline \hline
\end{tabular}

Source: Primary Data of 2020

From the results of the above table, it can be seen that the indicator no. 1 there are 28 respondents or $30,43 \%$ saying effective; 47 respondents or $51,09 \%$ saying less effective; 17 respondents or 18,48\% saying ineffective. Indicator no. 2 there are 19 respondents or $20,65 \%$ saying effective; 59 respondents or $64,13 \%$ saying less effective; 14 respondents or 15,22\% saying ineffective. Indicator no. 3 there are 28 respondents or $30,44 \%$ saying effective; 52 respondents or $56,52 \%$ saying less effective; 12 respondents or 13,04\% saying ineffective. Indicator no. 4 there are 19 respondents or $20,65 \%$ saying effective; 57 respondents or $61,96 \%$ saying less effective; 16 respondents or $17,39 \%$ saying ineffective.

Based on the description of the results of the acquisition of data above, it can be concluded that effectiveness based on aspects of safeguarding targets of South Sulawesi Regional Police Ditintelkam regarding the object of the dispute in South Sulawesi Province still less effective.

\section{B. Safeguarding Implementation}

Safeguarding implementation consists of three stages and includes the safeguarding targets referred to in Article 4 Perkap BIN No. 2 of 2013. Furthermore, the safeguarding implementation is based on Perkap BIN No. 2 of 2013, among others as follows:

1. Article 12 paragraph (1), set about "safeguarding preparation stage of the people/personnel".

2. Article 13 paragraph (1), set about "safeguarding implementation stage of the people/personnel".

3. Article 14, set about "safeguarding termination stage of the people/personnel".

4. Article 15 paragraph (1), set about "safeguarding preparation stage of the object/material/installation/place/location".

5. Article 16 paragraph (1), set about "safeguarding implementation stage of the object/material/installation/place/location".

6. Article 17, set about "safeguarding termination stage of the object/material/ installation/place/location". 
7. Article 18 paragraph (1), set about "safeguarding preparation stage of the activity".

8. Article 19 paragraph (1), set about "safeguarding implementation stage of the activity".

9. Article 20, set about "safeguarding termination stage of the activity".

10. Article 21, set about "safeguarding preparation stage of the data/information".

11. Article 22, set about "safeguarding implementation stage of the data/information".

12. Article 23, set about "safeguarding termination stage of the data/information".

The results of interviews with respondents regarding effectiveness based on aspects of safeguarding implementation of South Sulawesi Regional Police Ditintelkam can be seen in the following table:

Table 2. Safeguard Effectiveness of South Sulawesi Regional Police Ditintelkam based on Aspects of Safeguarding Implementation

\begin{tabular}{|c|c|c|c|c|c|c|c|c|c|}
\hline \multirow{2}{*}{ No. } & \multirow{2}{*}{ Indicator } & \multicolumn{2}{|c|}{ Effective } & \multicolumn{2}{|c|}{$\begin{array}{c}\text { Less } \\
\text { Effective }\end{array}$} & \multicolumn{2}{|c|}{ Ineffective } & \multicolumn{2}{|c|}{ Total } \\
\hline & & $\mathbf{F}$ & $\%$ & $\mathbf{F}$ & $\%$ & $\mathbf{F}$ & $\%$ & $\mathbf{F}$ & $\%$ \\
\hline 1. & $\begin{array}{l}\text { Safeguarding Preparation Stage of } \\
\text { the People/Personnel }\end{array}$ & 29 & 31,52 & 44 & 47,83 & 19 & 20,65 & 92 & 100 \\
\hline 2. & $\begin{array}{l}\text { Safeguarding Implementation Stage } \\
\text { of the People/Personnel }\end{array}$ & 28 & 30,43 & 51 & 55,44 & 13 & 14,13 & 92 & 100 \\
\hline 3. & $\begin{array}{l}\text { Safeguarding Termination Stage of } \\
\text { the People/Personnel }\end{array}$ & 31 & 33,70 & 44 & 47,83 & 17 & 18,47 & 92 & 100 \\
\hline 4. & $\begin{array}{l}\text { Safeguarding Preparation Stage of } \\
\text { the Object/Material/Installation/ } \\
\text { Place/Location }\end{array}$ & 35 & 38,04 & 43 & 46,74 & 14 & 15,22 & 92 & 100 \\
\hline 5. & $\begin{array}{l}\text { Safeguarding Implementation Stage } \\
\text { of the Object/Material/Installation/ } \\
\text { Place/Location }\end{array}$ & 29 & 31,52 & 48 & 52,17 & 15 & 16,31 & 92 & 100 \\
\hline 6. & $\begin{array}{l}\text { Safeguarding Termination Stage of } \\
\text { the Object/Material/Installation/ } \\
\text { Place/Location }\end{array}$ & 31 & 33,70 & 45 & 48,91 & 16 & 17,39 & 92 & 100 \\
\hline 7. & $\begin{array}{l}\text { Safeguarding Preparation Stage of } \\
\text { the Activity }\end{array}$ & 25 & 27,17 & 55 & 59,78 & 12 & 13,05 & 92 & 100 \\
\hline 8. & $\begin{array}{l}\text { Safeguarding Implementation Stage } \\
\text { of the Activity }\end{array}$ & 31 & 33,70 & 48 & 52,17 & 13 & 14,13 & 92 & 100 \\
\hline 9. & $\begin{array}{l}\text { Safeguarding Termination Stage of } \\
\text { the Activity }\end{array}$ & 26 & 28,26 & 55 & 59,78 & 11 & 11,96 & 92 & 100 \\
\hline 10. & $\begin{array}{l}\text { Safeguarding Preparation Stage of } \\
\text { the Data/Information }\end{array}$ & 31 & 33,69 & 46 & 50,00 & 15 & 16,31 & 92 & 100 \\
\hline 11. & $\begin{array}{l}\text { Safeguarding Implementation Stage } \\
\text { of the Data/Information }\end{array}$ & 18 & 19,56 & 60 & 65,22 & 14 & 15,22 & 92 & 100 \\
\hline 12. & $\begin{array}{l}\text { Safeguarding Termination Stage of } \\
\text { the Data/Information }\end{array}$ & 29 & 31,52 & 45 & 48,91 & 18 & 19,57 & 92 & 100 \\
\hline
\end{tabular}

Source: Primary Data of 2020

From the results of the above table, it can be seen that the indicator no. 1 there are 29 respondents or 31,52 saying effective; 44 respondents or 47,83 saying 
less effective; 19 respondents or $20,65 \%$ saying ineffective. Indicator no. 2 there are 28 respondents or 30,43 saying effective; 51 respondents or 55,44 saying less effective; 13 respondents or 14,13\% saying ineffective. Indicator no. 3 there are 31 respondents or 33,70 saying effective; 44 respondents or 47,83 saying less effective; 17 respondents or 18,47\% saying ineffective. Indicator no. 4 there are 35 respondents or 38,04 saying effective; 43 respondents or 46,74 saying less effective; 14 respondents or $15,22 \%$ saying ineffective. Indicator no. 5 there are 29 respondents or 31,52 saying effective; 48 respondents or 52,17 saying less effective; 15 respondents or 16,31\% saying ineffective. Indicator no. 6 there are 31 respondents or 33,70 saying effective; 45 respondents or 48,91 saying less effective; 16 respondents or 17,39\% saying ineffective. Indicator no. 7 there are 25 respondents or 27,17 saying effective; 55 respondents or 59,78 saying less effective; 12 respondents or 13,05\% saying ineffective. Indicator no. 8 there are 31 respondents or 33,70 saying effective; 48 respondents or 52,17 saying less effective; 13 respondents or $14,13 \%$ saying ineffective. Indicator no. 9 there are 26 respondents or 28,26 saying effective; 55 respondents or 59,78 saying less effective; 11 respondents or $11,96 \%$ saying ineffective. Indicator no. 10 there are 31 respondents or 33,69 saying effective; 46 respondents or 50,00 saying less effective; 15 respondents or 16,31\% saying ineffective. Indicator no. 11 there are 18 respondents or 19,56 saying effective; 60 respondents or 65,22 saying less effective; 14 respondents or $15,22 \%$ saying ineffective. Indicator no. 12 there are 29 respondents or 31,52 saying effective; 45 respondents or 48,91 saying less effective; 18 respondents or $19,57 \%$ saying ineffective.

Based on the description of the results of the acquisition of data above, it can be concluded that effectiveness based on aspects of safeguarding implementation of South Sulawesi Regional Police Ditintelkam regarding the object of the dispute in South Sulawesi Province still less effective.

\section{Coordination and Administration}

Provisions coordination and administration is based on Perkap BIN No. 2 of 2013, among others as follows:

1. Article 24 paragraph (1), set about "Safeguard executor of the Intelligence which is open to coordination with the object/target safeguard".

2. Article 24 paragraph (2), set about "Safeguard executor of the Intelligence which is closed to coordination with the object/target safeguard".

3. Article 25 paragraph (1), set about "Administration implementation is based on the administration of intelligence products".

4. Article 25 paragraph (2), set about "Logistics support using infrastructure as needed". 
5. Article 25 paragraph (3), set about "Budget support is adjusted to the index and the needs of activities/operations safeguard of the Intelligence".

The results of interviews with respondents regarding effectiveness based on aspects of coordination and administration of South Sulawesi Regional Police Ditintelkam can be seen in the following table:

Table 3. Safeguard Effectiveness of South Sulawesi Regional Police Ditintelkam based on Aspects of Coordination and Administration

\begin{tabular}{c|l|c|c|c|c|c|c|c|c}
\hline \hline \multirow{2}{*}{ No. Indicator } & \multicolumn{2}{c|}{ Effective } & \multicolumn{2}{c|}{$\begin{array}{l}\text { Less } \\
\text { Effective }\end{array}$} & \multicolumn{2}{c|}{ Ineffective } & \multicolumn{2}{c}{ Total } \\
\cline { 3 - 10 } & & F & $\%$ & F & $\%$ & F & $\%$ & F & $\%$ \\
\hline \hline 1. & $\begin{array}{l}\text { Safeguard Executor of the } \\
\text { Intelligence Which is Open to } \\
\text { Coordination with the Object/Target } \\
\text { Safeguard }\end{array}$ & 26 & 28,26 & 51 & 55,44 & 15 & 16,30 & 92 & 100 \\
\hline & $\begin{array}{l}\text { Safeguard Executor of the } \\
\text { Intelligence Which is Closed to } \\
\text { Coordination with the Object/Target } \\
\text { Safeguard }\end{array}$ & 26 & 28,26 & 49 & 53,26 & 17 & 18,48 & 92 & 100 \\
\hline 3. & $\begin{array}{l}\text { Administration Implementation } \\
\text { is based on the Administration of } \\
\text { Intelligence Products }\end{array}$ & 25 & 27,17 & 54 & 58,70 & 13 & 14,13 & 92 & 100 \\
\hline 4. & $\begin{array}{l}\text { Logistics Support using } \\
\text { Infrastructure as Needed }\end{array}$ & 25 & 27,17 & 55 & 59,78 & 12 & 13,05 & 92 & 100 \\
\hline 5. & $\begin{array}{l}\text { Budget Support is Adjusted to the } \\
\text { Index and the Needs of Activities/ } \\
\text { Operations Safeguard of the } \\
\text { Intelligence }\end{array}$ & 31 & 33,70 & 45 & 48,91 & 16 & 17,39 & 92 & 100 \\
\hline \hline
\end{tabular}

Source: Primary Data of 2020

From the results of the above table, it can be seen that the indicator no. 1 there are 26 respondents or 28,26\% saying effective; 51 respondents or 55,44\% saying less effective; 15 respondents or 16,30\% saying ineffective. Indicator no. 2 there are 26 respondents or $28,26 \%$ saying effective; 49 respondents or $53,26 \%$ saying less effective; 17 respondents or 18,48\% saying ineffective. Indicator no. 3 there are 25 respondents or $27,17 \%$ saying effective; 54 respondents or $58,70 \%$ saying less effective; 13 respondents or $14,13 \%$ saying ineffective. Indicator no. 4 there are 25 respondents or $27,17 \%$ saying effective; 55 respondents or $59,78 \%$ saying less effective; 12 respondents or $13,05 \%$ saying ineffective. Indicator no. 5 there are 31 respondents or 33,70\% saying effective; 45 respondents or 48,91\% saying less effective; 16 respondents or 17,39\% saying ineffective.

Based on the description of the results of the acquisition of data above, it can be concluded that effectiveness based on aspects of coordination and administration of South Sulawesi Regional Police Ditintelkam regarding the object of the dispute in South Sulawesi Province still less effective. 


\section{Supervision and Controlling}

Based on Article 26 Perkap BIN No. 2 of 2013 regulates that:

(1) Supervision and controlling in the implementation of safeguard of the Intelligence structurally carried out by police intelligence officers.

(2) Supervision in the implementation of safeguard of the Intelligence functionally done starting from Sponsor (SP), Agent Handler (AH), Principal Agent (PA), Support Agent (SA), and Agent Action (AA).

The results of interviews with respondents regarding effectiveness based on aspects of supervision and controlling of South Sulawesi Regional Police Ditintelkam can be seen in the following table:

Table 4. Safeguard Effectiveness of South Sulawesi Regional Police Ditintelkam based on Aspects of Supervision and Controlling

\begin{tabular}{|c|c|c|c|c|c|c|c|c|c|}
\hline \multirow[t]{2}{*}{ No. } & \multirow[t]{2}{*}{ Indicator } & \multicolumn{2}{|c|}{ Effective } & \multicolumn{2}{|c|}{$\begin{array}{c}\text { Less } \\
\text { Effective }\end{array}$} & \multicolumn{2}{|c|}{ Ineffective } & \multicolumn{2}{|c|}{ Total } \\
\hline & & $\mathbf{F}$ & $\%$ & $\mathbf{F}$ & $\%$ & $\mathbf{F}$ & $\%$ & $\mathbf{F}$ & $\%$ \\
\hline 1. & $\begin{array}{l}\text { Supervision of the Implementation } \\
\text { of Safeguard of the Intelligence } \\
\text { Structurally }\end{array}$ & 22 & 23,91 & 59 & 64,13 & 11 & 11,96 & 92 & 100 \\
\hline 2. & $\begin{array}{l}\text { Controlling of the Implementation } \\
\text { of Safeguard of the Intelligence } \\
\text { Structurally }\end{array}$ & 26 & 28,26 & 52 & 56,52 & 14 & 15,22 & 92 & 100 \\
\hline 3. & $\begin{array}{l}\text { Supervision of the Implementation } \\
\text { of Safeguard of the Intelligence } \\
\text { Functionally }\end{array}$ & 19 & 20,65 & 56 & 60,87 & 17 & 18,48 & 92 & 100 \\
\hline 4. & $\begin{array}{l}\text { Controlling of the Implementation } \\
\text { of Safeguard of the Intelligence } \\
\text { Functionally }\end{array}$ & 28 & 30,44 & 49 & 53,26 & 15 & 16,30 & 92 & 100 \\
\hline
\end{tabular}

Source: Primary Data of 2020

From the results of the above table, it can be seen that the indicator no. 1 there are 22 respondents or $23,91 \%$ saying effective; 59 respondents or $64,13 \%$ saying less effective; 11 respondents or 11,96\% saying ineffective. Indicator no. 2 there are 26 respondents or $28,26 \%$ saying effective; 52 respondents or $56,52 \%$ saying less effective; 14 respondents or 15,22\% saying ineffective. Indicator no. 3 there are 19 respondents or $20,65 \%$ saying effective; 56 respondents or $60,87 \%$ saying less effective; 17 respondents or 18,48\% saying ineffective. Indicator no. 4 there are 28 respondents or $30,44 \%$ saying effective; 49 respondents or $53,26 \%$ saying less effective; 15 respondents or 16,30\% saying ineffective.

Based on the description of the results of the acquisition of data above, it can be concluded that effectiveness based on aspects of supervision and controlling of South Sulawesi Regional Police Ditintelkam regarding the object of the dispute in South Sulawesi Province still less effective. 


\section{CONCLUSION}

From the description of the results and discussion above, safeguard the effectiveness of South Sulawesi Regional Police Ditintelkam in the execution process regarding the object of the dispute in South Sulawesi Province based on Perkap BIN No. 2 of 2013, can be assessed from four aspects, as follows: Safeguarding Targets; Safeguarding Implementation; Coordination and Administration; and Supervision and Controlling. Data acquisition of all indicators based on safeguard aspects of the South Sulawesi Regional Police Ditintelkam still shows less effective results. Seriousness is needed in increasing the safeguard effectiveness at the South Sulawesi Regional Police Ditintelkam to ensure the process of executing court decisions regarding the object of the dispute can be more effective in the future.

\section{REFERENCE}

Aziezi, M. Tanziel, et al. (2019). Kertas Kebijakan Penguatan Sistem Eksekusi Sengketa Perdata di Indonesia. Jakarta: Lembaga Kajian dan Advokasi untuk Independensi Peradilan (LeIP).

Bachar, Djazuli. (2008). Eksekusi Putusan Perkara Perdata: Segi Hukum dan Penegakan Hukum. Jakarta: Akademika Pressindo.

Editorial. (2018, 19 April). Eksekusi dalam Teori dan Praktek. In Fakultas Hukum Universitas Indonesia. Retrieved from https://law.ui.ac.id/v3/eksekusi-dalamteori-dan-praktek/, at the date on February 28, 2020.

Harahap, M. Yahya. (2007). Ruang Lingkup Permasalahan Eksekusi Bidang Perdata. Jakarta: PT. Gramedia Pustaka Utama.

Harefa, Herius, Fitriati, Fitriati, \& Ferdi, Ferdi. (2018). Optimalisasi Fungsi Intelijen Kepolisian dalam Penyelidikan Tindak Pidana Narkotika yang Dilakukan Anggota Kepolisian (Studi Sat Intelkam Polres Solok). Unes Law Review, Universitas Ekasakti Padang, 1(1), 44 - 52. doi: https://doi.org/10.31933/law.v1i1.5

Husen, La Ode \& Thamrin, Husni. (2017). Hukum Konstitusi: Kesepakatan (Agreement) dan Kebiasaan (Custom) Sebagai Pilar Konvensi Ketatanegaraan. Makassar: CV. Social Politic Genius (SIGn).

Husen, La Ode, et al. (2020). Pengamanan Intelijen Kepolisian Terhadap Putusan Pengadilan Atas Objek Sengketa. SIGn Jurnal Hukum, CV. Social Politic Genius (SIGn), 1(2), 136 - 148. doi: https://doi.org/10.37276/sjh.v1i2.62

Jebabun, Alfeus, et al. (2018). Asesmen Awal Permasalahan Eksekusi Putusan Perkara Perdata di Indonesia. Jakarta: Lembaga Kajian dan Advokasi untuk Independensi Peradilan (LeIP) in collaboration with International Development Law Organization (IDLO).

Law of the Republic of Indonesia Number 2 of 2002 on the State Police of the Republic of Indonesia. State Gazette of the Republic of Indonesia of 2002 Number 2. Supplement to the State Gazette of the Republic of Indonesia Number 4168. 
Law of the Republic of Indonesia Number 48 of 2009 on The Judicial Powers. State Gazette of the Republic of Indonesia of 2009 Number 157. Supplement to the State Gazette of the Republic of Indonesia Number 5076.

Law of the Republic of Indonesia Number 17 of 2011 on State Intelligence. State Gazette of the Republic of Indonesia of 2011 Number 105. Supplement to the State Gazette of the Republic of Indonesia Number 5249.

Penyusun (Ed.) (2019). Pedoman Eksekusi pada Pengadilan Negeri. Jakarta: Direktorat Jenderal Badan Peradilan Umum, Mahkamah Agung RI.

Pratama, Widhy Andrian. (2019). Penegakan Hukuman Mati terhadap Pembunuhan Berencana. SIGn Jurnal Hukum, CV. Social Politic Genius (SIGn), 1(1), 29 - 41. doi: https://doi.org/10.37276/sjh.v1i1.34

Qamar, Nurul, et al. (2018). Negara Hukum atau Negara Kekuasaan (Rechtsstaat or Machtstaat). Makassar: CV. Social Politic Genius (SIGn).

Rahardjo, Satjipto. (2009). Penegakan Hukum: Suatu Tinjauan Sosiologis. Yogyakarta: Genta Publishing.

Regulation of the Head of Security Intelligence Agency of the State Police of the Republic of Indonesia Number 2 of 2013 on Safeguard of the State Police Intelligence of the Republic of Indonesia. Registration of the General Secretariat of the State Police of 2013 Number 11.

Regulation of the State Police of the Republic of Indonesia Number 14 of 2018 on Organization Structure and Work Procedure of the Regional Police. State Bulletin of the Republic of Indonesia of 2018 Number 1450.

S., Laurensius Arliman. (2019). Mewujudkan Penegakan Hukum yang Baik di Negara Hukum Indonesia. Dialogia Iuridica: Jurnal Hukum Bisnis dan Investasi, Universitas Kristen Maranatha, 11(1), 1 - 20. doi: https://doi.org/10.28932/di.v11i1.1831

Sagama, Suwardi.(2016). Analisis Konsep Keadilan, Kepastian Hukum dan Kemanfaatan dalam Pengelolaan Lingkungan. Mazahib: Jurnal Pemikiran Hukum Islam, Institut Agama Islam Negeri Samarinda, 15(1), 20 - 41. doi: https://doi.org/10.21093/ mj.v15i1.590

Sonata, Depri Liber. (2012). Permasalahan Pelaksanaan Lelang Eksekusi Putusan Pengadilan dalam Perkara Perdata dalam Praktik. Fiat Justisia: Jurnal Ilmu Hukum, Universitas Lampung, 6(2), 1 - 19. doi: https://doi.org/10.25041/ fiatjustisia.v6no2.329

Staatsblad Number 44 of 1941 on Herzien Inlandsch Reglement.

The 1945 Constitution of the Republic of Indonesia.

I Husen, La Ode, et al. (2020). Safeguard of the Police Intelligence Against Court Decisions

Regarding the Object of the Dispute. Sovereign: International Journal of Law, CV. Social

I Politic Genius (SIGn), 2(2), 1 - 12. doi: https://doi.org/10.37276/sijl.v2i2.28 